\title{
Work-Life Balance and Job Stress Among Female Faculties in India's Higher Education Institutions
}

\author{
Sayeda Meharunisa
}

\begin{abstract}
Job stress is present in all types of organizations, even in higher educational institutions. There are various factors that cause stress in the workplace including unwarranted demands and apparent pressures of the work situation and aptitude of the individuals to balance their professional and personal lives. The aim of this paper is to identify the causes of job stress along with studying the impact of stress in maintaining work life balance among female faculties in India's higher education institutions. This study selected a sample of 208 women faculty members employed in higher educational institutions in Northern India in order to collect primary quantitative data from them using structured close-ended questionnaires. The collected data was analysed using SPSS Software and it was found that improper pay structure and hectic work schedules were the main causes of stress in workplace. In addition, it was also found that due to these stresses has caused a financial problem as well as a decrease in the productivity of the female faculties affecting their work life. Thus, it was implicated that there is a positive relationship between stress and work life.
\end{abstract}

Keywords: Stress, Worklife balance, Role conflict, Education

\section{INTRODUCTION}

An introduction to the growth of job stress in the education sector and the causative factors

Job stress can be defined as the harmful physical and emotional responses that occur when the requirement of the job do not match the capabilities, resources, or needs of the workers (Ursin\&Eriksen, 2010). (Mehta, 2011) identified the various factors of organizational stress among the management teachers and found that role stagnation, competing style, role erosion along with avoiding style were amongst the main contributors to stress in the education sector. Also, (Vijaydura\&Vekatesh, 2012) found in their study that workplace stress occurs when there are imbalanced demands and perceived pressures of the work environment and an individual ability to cope. (Mehta, 2011) also indicated that especially in case of female workers, a poor working environment or unsafe environment also causes stress amongst working women.

The situation of job satisfaction and attrition in the higher education system of India

Employee satisfaction can be regarded as being utmost important in a company as it has a direct impact on employee productivity as high quality teaching personnel is the

Revised Version Manuscript Received on 16 September, 2019.

Dr.SayedaMeharunisa,Assistant Professor, College of Business Administration, Princess Nora Bint Abdul Rahman University, Riyadh, Saudi Arabia.

(Email: smeharunisa@pnu.edu.sa) foundation stone on which the educational institution is based. The increased attrition rate in education institutions necessitates the attraction as well as retention of high quality teacher (Sharma \&Jyoti, 2010).

Ensuring job satisfaction of teachers is a versatile experience (Sharma \&Jyoti, 2010; Srivastava, Holani, \&Bajpai, 2015) which is significant in employee turnover, commitment towards the organization, and school effectiveness. Retaining high performing employees is of great importance to educational institutions as it eliminates the recruitment, selecting and on-boarding costs which would otherwise be incurred in replacing them (Tymon, Stumpf, \& Smith, 2011, 293).

\section{Aim of the paper}

Job satisfaction and employee turnover are major concerns for higher education institutions due to the shift of highly qualified employees to other sectors or other institutions that offer better rewards and benefits which leads to the increasing need to ensure job satisfaction. The aim of this paper is to explore the relationship between work life balance and job stress among female faculties in India's higher education institutions.

\section{LITERATURE REVIEW}

\section{Introduction to job stress and work life balance}

Job stress is a very common situation that is faced by employees of all levels and is the after effect of the job requirements and the resources available to achieve the demands of the job. Job stress can be regarded as the detrimental physical and expressive responses which happen when the requirements of the job do not match the capabilities, resources, or needs of the worker (Michie, 2002). It has a significant impact on the psychological and physical health of the employees as well as their productivity. Previous studies have shown that extreme job stress can cause a lot of health problems in individuals including high blood pressure, depression and high anxiety (Balkan, 2014a).

Work life balance, on the other hand is a state where a person tends to balance two environment at once, work and personal (Chandra, 2012). The environment of work is usually stressful and may lead an employee to even work for long hours may also have to look after the family who is 
married and has children. Now managing time between these two environments is work life balance. However, work life balance has rarely been considered as positive aspect and mostly considered as a negative aspect.

\section{Causes of job stress and its impact on work life balance}

The most common causes of job stress include excessively high workloads, impractical deadlines which make employees feel hurried, under pressure and inundated along with making the employees feel under used or overused. They also feel harassed if they feel a lack of control over work activities along with lack of interpersonal support or poor working relationships and may even lead to bully and harassment by colleagues. Some employees might be having difficulty settling into a new promotion, both in terms of meeting the new role's demands and adapting to possible changes in relationships with colleagues (Mehta \& Sharma, 2015). These are the major causes of job- or work-related stress.

Other main causes might be related to job security, be deficient in of occupation opportunities, or level of pay along with facing bullying. A weak or ineffective management might leave the employees without a sense of direction while over-management can leave employees feeling undervalued and affect their self-esteem(Bhargava\&Trivedi, 2018).Job stress as well as work life conflict lead to similar impact like job accidents and low performance. There are various companies even in developed countries that make use of practices like flexible working hours and career break in order to help the employees in attaining family demands as well as demands of the work (Sliter\& Yuan, 2015). High performing employees make efforts to balance their unfavourable effects outside their workplace. The conflict between work and family life can also lead the employee to make the decision to leave the company.

A study by (Mache, Bernburg, Groneberg, Klapp, \&Danzer, 2016) indicated there is a significant relationship between job stress and work life balance by implicating that change in the salary causes financial issue hampers the financial management for home or personal life, similarly, increased pressure will cause the person to work longer hours thereby spending less time with family. In such case, the work life balance is unstable. Again, when there is increased working pressure there is a stress to complete in the stipulated time and chance of poor performance, leading the employee to spend more time in office than home (Kotteeswari\&Sharief, 2014). Any unexpected pressure or move in the working environment may affect a person's or all the employee's leads the person to lose work life balance.

\section{Factors affecting work life balance and its importance}

Work life conflict occurs where the high position of the person necessitates him or her to work for longer hours and therefore, experience difficulty in maintaining the balance between work and home (Chandra, 2012). This negative relation is termed as "role conflict" and it emerges due to the inaptness of activities between the domains of work and family and puts more emphasis on the fact that the crossing point between family and work can be regarded as a zero-sum game (Akanji, 2012). (Duxbury, Higgins, \&Coghill, 2013) found that $10 \%$ of the respondents of the survey conducted by Health Canada were of the opinion that they faced high interference of family to work and personal circumstances along with their responsibilities towards their family outside of work were posing a hurdle in front of them from becoming more productive in their work. Thus, it can be seen that both work to family enrichment as well as family to work enrichment needs to be well thought out for obtaining a better understanding of the work-family interface (Khairunneezam, Suriani, \&Nadirah, 2017). Again, (Kotteeswari\&Sharief, 2014) and (Mache et al., 2016) indicated various factors like time to relax and recharge, poor performance level, long hours of working, prolonged stress based issues, imbalanced schedule and hours, demographic factors, family based issues and many other to name

Empirical review: Job stress and Work life balance in the higher education sector

(Punia\&Kaboj, 2013)investigated the quality of work-life balance among Indian teachers. It was found that the factors that affected their work life balance included designation of the teachers, their nature of appointment, the academic stream in which they are teaching, and the nature of their serving institution but no variation was found on the basis of gender and marital status.

Another study by (Balkan, 2014) studied on the relationship between work-life balance, job stress and individual performance amongst postgraduate and doctoral students in Turkey. Based on the statistical analyses it was found that a strong relation exists between job stress performance and work-life balance factors. It was also found that initially stress impacts individual performance of the students which leads to impact of work-life balance. Thus, this study is almost similar to the current study except for the participants of the study.

(Ramasamy\&Renganathan, 2017) discussed the components on quality of work life in the higher education sector and segregated them as important, moderately important and least important. The study found that work environment and work conditions, teacher autonomy, growth opportunities and involvement in the decision-making process were the important focus areas in order to improve work life quality as they were ranked as being significantly important by the employees in this sector.

(Khairunneezam et al., 2017) conducted semi-structured interviews and focus group interviews with seventeen academics from three public universities in Malaysia by using purposive and snowball sampling techniques. The study found mixed responses with respect to general feelings of satisfaction and work-life balance among the respondents. Also, working overtime and on weekends, family support, and impacts of work towards life were discussed among the respondents.

Based on the aim of the study and to show the relationship between stress and work life balance, the following conceptual framework has been formed as in fig 1 . 


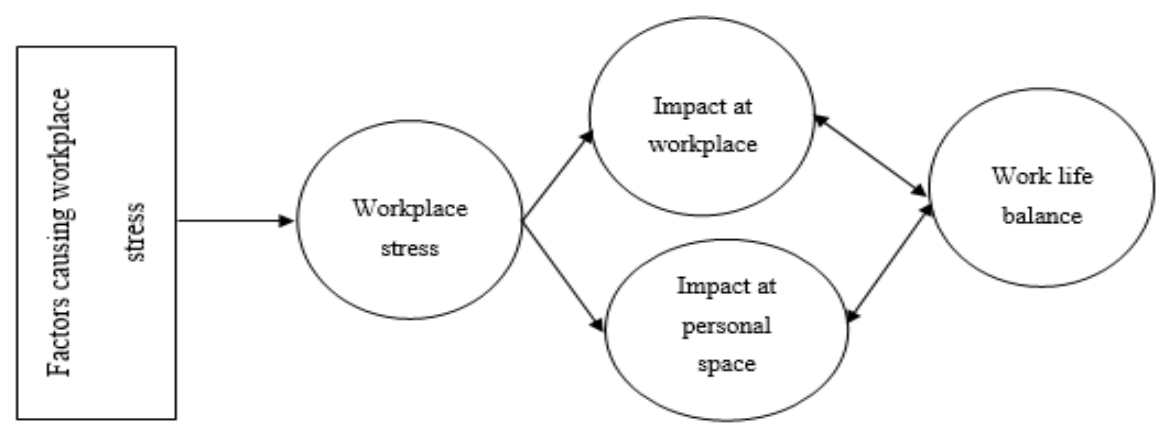

Figure 1: Conceptual framework

\section{METHODOLOGY}

In this section, research paradigm, philosophy, data collection as well as analysis procedure of quantitative and qualitative data has been presented. For the purpose of this research, interpretative research paradigm has been used as this study shall try to understand human nature. Also, subjectivist research philosophy has been employed as this study make ontological assumptions and the study of human nature requires some subjectivity from the author. The research purpose used in the study helped in dealing with the current predicament, whereas the approach explained the type of data that needed to be collected while defining the exacting sources of collection.

\section{DATA TYPE}

Data type may be primary or secondary, and primary research studies include collection of quantitative as well as qualitative data from the respondents (Kumar, 2011). For the purpose of this research, primary quantitative data shall be collected in order to understand the relationship between work life balance and job stress in the female faculties in India's higher educational institutions. The data shall be collected by selecting respondents out of the total population of female faculties and survey method will be used for the data collection and analysis methods. Since the main aim of the study is to show the relationship between workplace stress and work life balance.

\section{SAMPLING PLAN}

The selection of sample in quantitative research is done for the purpose of drawing of inferences from the chosen group, as against obtaining an in depth information of the subject in qualitative research (Kumar, 2011). Sample size is the total number of respondents that are required to be chosen out of the entire target population for collecting the data for the study. The sample size in this study was influenced by theoretical concerns of the study and the accessible resources. Therefore, for the purpose of this study, a sample of 208 women faculty members from different higher education institutions in Northern India was selected regarding their work life balance situation and its impact on their job stress. The study uses random purposive sampling technique for the purpose of selecting the sample from the universe. It should be noted that also female faculty members were considered for the purpose of data collection for this study as the scope of this study is restricted to women only.

\section{DATA COLLECTION AND ANALYSIS METHODS}

The measuring tool used for the purpose of this study was a structured close-ended questionnaire for the respondents to collect primary data. After selecting the sample, questionnaires were administered to them in order to collect relevant data by contacting the dean or the administration of the chosen universities. They respected members were then explained about the importance and the purpose of the study. After their acceptance, the department heads helps in distributing the questionnaires amongst only the female faculty members of any age or year of experience or type of employment. The questionnaire consisted of four parts, namely, demographic profile, general background, impact of stress on work-life and factors causing stress. The demographic profile sought to collect information including age, experience, marital status, designation, type of employment, educational qualification and annual income. The general background section was used to identify if the respondent was under stress and to identify the main causes of it. The questionnaire also tried to identify the causes of stress pertaining specifically to the job-related causes of stress and the impact of stress in balancing the work-life relationship. In the third section, the respondents were asked to rate the ten identified impacts of stress on their lives on a Likert scale of 1 to 5 , where 1 being strongly disagree and 5being strongly agree. Similarly, 12 factors of stress identified were also asked to be rated on a Likert scale.

The data thus collected was analysed using SPSS software and frequency analysis, correlation, regression, ANOVA analysis were conducted. The quantitative data collected from the respondents was in unprocessed type and was essential to be processed and analysed to obtain conclusions. The data was appropriately coded and entered SPSS, statistical software package, for the purpose of performing the descriptive and inferential data analysis. The descriptive statistics was used to summarize the necessary information enclosed in the data, relating the broad characteristics of the 
population. Also, factor analysis was performed in order to derive the various factors that led to job induced stress in the respondents and correlation analysis helped in identifying if there was any relationship between job stress and work-life balance. Regression analysis helped in assessing the magnitude of impact of stress on work-life balance.

\section{Analysis}

Data analysis is the process used to examine, refine, edit along with model the collected data for the reason of obtaining pertinent information and constructing appropriate decisions by getting information from the raw data collected (Hair, Black, Babin, \& Anderson, 2009). Also, it is important to draw relevant conclusions after the process of data analysis is complete. The primary data that was collected using the questionnaire was analysed using the SPSS v23 software package in order to derive descriptive as well as inferential statistics from it to understand the demographics, general background, factors causing stress as well as the impact of stress on the work life of the respondents.

\section{DESCRIPTIVE ANALYSIS}

\section{Demographic analysis}

Most of the respondents were in the age group of 31 to 40 years $(43.8 \%)$, followed by 24 to 30 years $(28.4 \%)$ with very few respondents above the age of 50 years $(5.8 \%)$. The years of teaching experience lie mostly between 5 to 10 years $(53.8 \%)$, followed by 1 to 4 years $(24.5 \%)$ with a smaller number of respondents with less than 1 year or more than 10 years' experience. Out of these, a big majority of them had been employed in their current institution for 1 to 4 years, followed by less than 1 year with very less respondents who had worked in this institution for more than 5 years. Regarding the marital status, it was found that around $60 \%$ of the respondents were married and $17.8 \%$ were unmarried with the rest being divorced or widowed and $9.1 \%$ of the respondents chose not to disclose the same. The designation of the respondents was mixed with the highest percentage being of lecturers, followed by professors, assistant professors and assistant lecturers. A massive $80 \%$ of the respondents were in regular employment of the institution with the balance being guest lecturer or in ad-hoc employment. Since the respondents belonged to high academic designations, it was found that more than half of the respondents were post-graduates, 25 per cent were doctorates and the rest being graduates or M.Phils. The annual income of most of the respondents ranged between 5 and 10 lakhs, followed by 3 to 5 lakhs and equal percent of respondents with less than 3 lakhs and more than 10 lakhs.

\section{General background}

A staggering 67.8 per cent of the respondents were facing stress currently with the most prominent reason being professional issues. The other reasons for stress as mentioned by the respondents included family and personal issues $(15.9 \%)$, health issues (13\%), social issues (5.3\%) and lifestyle reasons $(4.3 \%)$. Also, $71.6 \%$ of the respondents have faced stress at some point in their professional life. The main ssues faced by them in their professional lives included long working hours, hectic work schedule and harassment by colleagues. The level of stress as informed by the respondents ranged from moderate to high. Around $38 \%$ of the respondents accepted to having taken therapeutic sessions in order to alleviate stress while $55 \%$ declined. A very high percentage $(77 \%)$ of the respondents found it tough to balance their work life relationship mainly owing to the factors mentioned by them in the above questions.

\section{Reliability Test}

Cronbach's Alpha test has been employed to test the reliability of the data and face validation method has been employed in order to check the validity of the questionnaire. The value of Cronbach's alpha in this test is 0.93 which is very high and is regarded as "acceptable" in most research situations as it is recommended to have a minimum alpha coefficient of 0.65 to 0.8 in order to treat the research study as reliable. Cronbach's Alpha test was also employed to test the reliability of the data and face validation method has been employed in order to check the validity of the questionnaire for the factors causing stress. The value of Cronbach's alpha in this test is 0.928 which is very high and is regarded as "acceptable" in most research situations as it is recommended to have a minimum alpha coefficient of 0.65 to 0.8 in order to treat the research study as reliable.

Table 1: Reliability tests

\begin{tabular}{|c|c|c|}
\hline & $\begin{array}{c}\text { Cronbach's } \\
\text { Alpha }\end{array}$ & N of Items \\
\hline $\begin{array}{c}\text { Impact of stress } \\
\text { on work life }\end{array}$ & .930 & 10 \\
\hline $\begin{array}{c}\text { Factors causing } \\
\text { stress }\end{array}$ & .928 & 12 \\
\hline
\end{tabular}

\section{Hypothesis testing}

\section{Hypothesis 1}

\section{H01:}

Stress does not have a significant impact on work life of female faculties in India's higher educational institutions.

\section{HA1:}

Stress has a significant impact on work life of female faculties in India's higher educational institutions.

\section{Correlation}

Correlation analysis was done in order to find out the relationship between the different impacts of stress on work life. All the factors are positively correlated with each with most the values ranging between 0.5 and 0.6 indicating that they are moderately positively correlated. The highest correlation was found to exist between takings of stress medications and performing poorly in the workplace $(0.662)$ followed by between causing challenges in the personal lives and not being able to concentrate well while teaching $(0.65)$. The significance level of these factors is less than 0.05 which means that all these factors, namely, stress has impacted my 
personal life, stress has caused increased conflicts at home, stress has caused me to take medications and is deteriorating my health, stress from workplace has caused me to perform poorly on the institutional standards, due to stress I haven't been able to concentrate well while teaching my students, due to poor performance from stress I must stay longer to plan for my own children, stress has led to various personal conflicts with my family members, stress from poor work-life has also caused financial issues, stress from poor work-life has caused challenges in my private needs have a significant impact on the work life of the respondents and none of these factors can be removed from consideration at $95 \%$ CI. Table for correlation for hypothesis 1 is presented in appendices.

\section{ANOVA}

Regression analysis was performed in order to understand the magnitude of impact that the independent variables have on the dependent variable. It was found that these factors clearly explained the impact of stress on stress life as the $\mathrm{R}$-square value of the analysis is 0.947 . This means that $94.7 \%$ of the variation in work life could be explained by the various factors mentioned above. Moreover, from the ANOVA tests were carried out for the purpose of testing the hypothesis generated above. The table shows that the F-value of the regression model is 350.437 with significance level at 0.000 which means that the null hypothesis is rejected. Thus, it may be implicated that the predictors like challenges in private needs, perform poorly on the institutional standards, financial issues, not able to spend time with my own children, increased conflicts at home, take medications and is deteriorating my health and others to name has significant impact on work life of female faculties.

Table 2: ANOVA statistics for hypothesis 1

\begin{tabular}{|c|c|c|c|c|}
\hline R & R Square & $\begin{array}{c}\text { Adjusted R } \\
\text { Square }\end{array}$ & F & Sig. \\
\hline $.973^{\mathrm{a}}$ & .947 & .944 & 350.437 & $.000^{\mathrm{b}}$ \\
\hline
\end{tabular}

\section{Coefficients of regression}

The coefficients table shows the impact of different factors on the work life of the respondents. The coefficients of the regression model depict that all the factors have a positive impact on the work life of the respondents. All the values were found to be statistically significant at $\mathrm{p}<0.05$ and $95 \%$ CI. This indicates that the factors like Stress from poor work-life has caused challenges in my private needs, Stress from workplace has caused me to perform poorly on the institutional standards, Stress from poor work-life has also caused financial issues, Stress has led to various personal conflicts with my family members, Due to poor performance from stress I must stay longer to plan for improvements, Stress has impacted my personal life, Due to stress I am not able to spend time with my own children, Stress has caused increased conflicts at home, Stress has caused me to take medications and is deteriorating my health, Due to stress I haven't been able to concentrate well while teaching my students had p-values less than 0.05. The high coefficient values of these factors show that an improvement in stress level of the respondents shall lead to an improvement in their work life. This leads to accepting the alternative hypothesis that stress has a significant impact on the work life of female improvements, due to stress I am not able to spend time with

faculties in the higher educational institutions of India. Thus, the null hypothesis is rejected, and the alternative hypothesis is accepted.

Table 3: Regression statistics for hypothesis 1

\begin{tabular}{|c|c|c|c|}
\hline & & $\mathrm{t}$ & Sig. \\
\hline \multirow{10}{*}{$\begin{array}{c}\text { Independent } \\
\text { variables }\end{array}$} & $\begin{array}{l}\text { Stress has impacted my } \\
\text { personal life }\end{array}$ & 5.065 & .000 \\
\hline & $\begin{array}{c}\text { Stress has caused } \\
\text { increased conflicts at } \\
\text { home }\end{array}$ & 4.279 & .000 \\
\hline & $\begin{array}{l}\text { Stress has caused me to } \\
\text { take medications and is } \\
\text { deteriorating my health }\end{array}$ & 8.648 & .000 \\
\hline & $\begin{array}{l}\text { Stress from workplace has } \\
\text { caused me to perform } \\
\text { poorly on the institutional } \\
\text { standards }\end{array}$ & 6.008 & .000 \\
\hline & $\begin{array}{c}\text { Due to stress I haven’t } \\
\text { been able to concentrate } \\
\text { well while teaching my } \\
\text { students }\end{array}$ & 4.341 & .000 \\
\hline & $\begin{array}{l}\text { Due to poor performance } \\
\text { from stress I must stay } \\
\text { longer to plan for } \\
\text { improvements }\end{array}$ & 3.268 & .001 \\
\hline & $\begin{array}{l}\text { Due to stress I am not able } \\
\text { to spend time with my } \\
\text { own children }\end{array}$ & 2.092 & .038 \\
\hline & $\begin{array}{l}\text { Stress has led to various } \\
\text { personal conflicts with my } \\
\text { family members }\end{array}$ & 5.044 & .000 \\
\hline & $\begin{array}{c}\text { Stress from poor work-life } \\
\text { has also caused financial } \\
\text { issues }\end{array}$ & 6.444 & .000 \\
\hline & $\begin{array}{l}\text { Stress from poor work-life } \\
\text { has caused challenges in } \\
\text { my private needs }\end{array}$ & 4.755 & .000 \\
\hline
\end{tabular}

Hypothesis 2

HO2:

The working condition-based factors do not have an impact on the stress levels of female faculties in India's higher educational institutions

HA2:

The working conditions-based factors have an impact on the stress levels of female faculties in India's higher educational institutions

\section{Correlation}

Correlation analysis was done in order to find out the relationship between the different factors which cause stress in workplace. It can again be seen that all the factors from the working condition in universities are positively correlated with each with varying levels of correlation amongst the 
different factors. It means that any increase in these factors shall lead to an increase in the stress of the women faculties and vice-versa. The highest correlation was found to exist between working environment is negative and Institution is all about money making and does not care about the students followed by between work schedule is hectic and imparity or low levels of pay. The significance level of all these factors is less than 0.01 which means that all these factors, namely, pressure for student performance, institutional policies, pay is poor or imparity of pay, work schedule is hectic, extracurricular activities and management related tasks, poor appraisals and benefits, long working hours, harassment by colleagues (psychological and sexual), gender discrimination, lack of training and workshops for faculty, institution is all about money making and does not care about the students and working environment is negative have a significant impact on the work life of the respondents and none of these factors can be removed from consideration at $95 \%$ CI. Table of correlation for hypothesis 2 is presented in appendices.

\section{ANOVA}

Regression analysis was performed in order to understand the magnitude of impact that the independent variables have on the dependent variable. It was found that these factors clearly explained the causes of stress in work life as the $\mathrm{R}$-square value of the analysis is 0.947 . This means that $94.7 \%$ of the variation in work life could be explained by the various factors mentioned above. Again, from the ANOVA tests carried out for the purpose of testing the hypothesis generated above. The table shows that the F-value of the regression model is 292.261 with significance level at 0.000 which means that the null hypothesis is rejected. This leads to the suggestion that the null hypothesis is rejected and that the above-mentioned factors have an impact on the stress levels of female faculties in the higher educational institutions of India. Thus, factors like working environment is negative, pay is poor or imparity of pay, harassment by colleagues (psychological and sexual), gender discrimination, pressure for student performance, poor appraisals and benefits, institution is all about money making and does not care about the students, institutional policies, long working hours, extracurricular activities and management related tasks, work schedule is hectic, lack of training and workshops for faculty may have an impact on stress.

Table 4: ANOVA statistics for hypothesis 2

\begin{tabular}{|c|c|c|c|c|}
\hline $\mathrm{R}$ & R Square & $\begin{array}{c}\text { Adjusted R } \\
\text { Square } \\
\end{array}$ & $\mathrm{F}$ & Sig. \\
\hline .973 & .947 & .944 & 292.261 & $.000 \mathrm{~b}$ \\
\hline
\end{tabular}

\section{Coefficient of regression}

The coefficients table shows the impact of different factors on the work life of the respondents. The coefficients of the regression model depict that all the factors have a positive impact on the work life of the respondents except "Institution is all about money making and does not care about the students". The highest coefficient was of pay is poor or imparity of pay followed by work schedule is hectic, gender discrimination and lack of training and workshops for that faculty. The high coefficient values of these factors show that these factors have a significant impact on the stress value in their work life. It was found that out of 12 factors from the poor working conditions, 9 factors turned out to be significant at $\mathrm{p}<0.05$. These factors were; pressure for student performance, institutional policies, and pay is poor or imparity of pay, work schedule is hectic, extracurricular activities and management related tasks, poor appraisals and benefits, harassment by colleagues, gender discrimination, and lack of training and workshops for faculty. Thus, the null hypothesis that indicates working condition-based factors do not have an impact on the stress levels of female faculties in India's higher educational institutions is rejected and the alternative is accepted. Thus, the working conditions-based factors have an impact on the stress levels of female faculties in India's higher educational institutions.

Table 5: Regression statistics for hypothesis 2

\begin{tabular}{|c|c|c|c|}
\hline & & $\mathrm{t}$ & Sig. \\
\hline \multirow{12}{*}{$\begin{array}{l}\text { Independent } \\
\text { variables }\end{array}$} & $\begin{array}{l}\text { Pressure for student } \\
\text { performance }\end{array}$ & 4.844 & .000 \\
\hline & Institutional policies & 4.223 & .000 \\
\hline & Pay is poor or imparity of pay & 8.776 & .000 \\
\hline & Work schedule is hectic & 6.081 & .000 \\
\hline & $\begin{array}{l}\text { Extracurricular activities and } \\
\text { management related tasks }\end{array}$ & 4.197 & .000 \\
\hline & Poor appraisals and benefits & 3.209 & .002 \\
\hline & Long working hours & 1.941 & .054 \\
\hline & $\begin{array}{l}\text { Harassment by colleagues } \\
\text { (psychological and sexual) }\end{array}$ & 5.055 & .000 \\
\hline & Gender discrimination & 6.522 & .000 \\
\hline & $\begin{array}{l}\text { Lack of training and } \\
\text { workshops for faculty }\end{array}$ & 4.339 & .000 \\
\hline & $\begin{array}{l}\text { Institution is all about money } \\
\text { making and does not care } \\
\text { about the students }\end{array}$ & -1.119 & .265 \\
\hline & $\begin{array}{l}\text { Working environment is } \\
\text { negative }\end{array}$ & .534 & .594 \\
\hline
\end{tabular}

\section{DISCUSSIONS\& RESULTS}

The above analysis identified the various factors that cause stress in the work life of women faculty in India's higher educational institutions. The main factors were identified as lack of proper pay, hectic work schedule, gender discrimination and lack of training and workshops for that faculty. Also, it was found that stress had a significant impact on the work life of female faculty in the higher educational institutions of India. The main impact that stress has includes deterioration of their health forcing them to take medicines, decline in their productivity and causing financial problems in their personal lives.

\section{CONCLUSION}

The main objective of this study was to study the relationship between work life balance and job stress among 
female faculties in India's higher education institutions. The analysis showed the various factors of stress as well as the different impact that it has on the personal lives of the respondents, especially on maintaining the work life balance. This study shows that the physiological and social needs of the respondents need to be met in order to help them in managing their stress levels. Also, inadequate stress management of the women faculty leads to poor performance on their level.The study further revealed that family related stress factors lead to difficulty in maintaining the balance between their work life and personal life have an impact on the performance of the lecturers, professors and other women faculty in the higher educational institutions in India. Thus, based on the findings of the current study it may be implicated that workplace environment and factors has a significant impact of stress on the female faculty members which indirectly impacts their work life balance.

\section{RECOMMENDATIONS}

On the basis of the findings of this study, it can be suggested that the educational institutions need to revamp their compensation structure, reorganize the work schedule and provide appropriate training and development programs to the women faculty in order to improve their productivity as well as reduce their stress levels. It is also recommended that the institutes should discuss stress management with all lecturers, professors and their representatives in order to eradicate the major stress factors and to equally come up with ways to prevent and remove those factors. Another such recommendation is that educational departments need to take initiative for the purpose of being creative and innovative in teaching in order to help the women faculty in maintaining the balance between their work and personal lives.

\section{REFERENCES}

1. Akanji, B. (2012). Realities of work life balance in Nigeria. Business, Management and Education, 10(2), 248-263.

2. Balkan, O. (2014a). Work-life balance, job stress and individual performance: An application. International Journal of Management Sciences and Business Research, $3(3)$.

3. Balkan, O. (2014b). Work-Life Balance, Job Stress and Individual Performance: An Application. Work-Life Balance, Job Stress and Individual Performance: An Application Author Detail .Onur Balkan -Asst. Proffesor University of Turkish Aviation Association Turkey.

4. Bhargava, D. D., \&Trivedi, H. (2018). A Study of Causes of Stress and Stress Management among Youth. International Journal of Management and Social Sciences, 11(3), 108-117.

5. Chandra, V. (2012). Work life balancE: eastern and western perspectives. The International Journal of Human Resource Management, 23(5), 1040-1056.

6. Duxbury, L., Higgins, C., \&Coghill, D. (2013). Voices of canadians: Seeking woek life balance.

7. Hair, J. F., Black, W. C., Babin, B. J., \& Anderson, R. E. (2009). Multivariate data analysis. New York: Pearson Prentice Hall.

8. Khairunneezam, M. N., Suriani, S., \&Nadirah, A. H. N. (2017). Work-Life Balance Satisfaction among Academics in Public Higher Educational Sector. International Journal of Academic Research in Business and Social Sciences, 7.

9. Kotteeswari, M., \&Sharief, T. S. (2014). Job Stress and Its
Impact on Employees' Performance a Study With Reference To Employees Working in Bpos. International Journal of Business and Administration Research Review.

10. Kumar, R. (2011). Research Methodology- A stepbystep guide for beginners. New Age International (3rd ed.). SAGE Publications.

11. Mache, S., Bernburg, M., Groneberg, D. A., Klapp, B. F., \&Danzer, G. (2016). Work family conflict in its relations to perceived working situation and work engagement. Work. https://doi.org/10.3233/WOR-162257

12. Mehta, M., \& Sharma, V. (2015). Stress management. In A Practical Approach to Cognitive Behaviour Therapy for Adolescents.

https://doi.org/10.1007/978-81-322-2241-5_8

13. Mehta, S. (2011). Why do first-generation students fail? College Student Journal, 45(1), 2035.

14. Michie, S. (2002). Causes and management of stress at work. Occupational and Environmental Medicine. https://doi.org/10.1136/oem.59.1.67

15. Punia, V., \&Kaboj, M. (2013). Quality of Work-life Balance Among Teachers in HigherEducation Institutions. Learning Community, 4(3), 197-208.

16. Ramasamy, A., \&Renganathan, D. B. (2017). No QUALITY OF WORK LIFE IN THE HIGHER EDUCATION SECTOR: TOWARDS AN INTEGRATED OUTLOOK. International Journal of Management, 8(1), 62-72.

17. Sharma, R. D., \&Jyoti, J. (2010). Job satisfaction of university teachers: An empirical study. Journal of Service Research, 9(2).

18. Sliter, M., \& Yuan, Z. (2015). Workplace Stress. In International Encyclopedia of the Social \& Behavioral Sciences: Second Edition https://doi.org/10.1016/B978-0-08-097086-8.22041-2

19. Srivastava, S., Holani, U., \&Bajpai, N. (2015). Job satisfaction in public sector. Indian Management, 44(5), $62-65$.

20. Tymon, W. G., Stumpf, S. A., \& Smith, R. R. (2011). Manager support predicts turnover of professionals in India. Career Development International, 1(3), 293-312.

21. Ursin, H., \&Eriksen, H. R. (2010). Cognitive activation theory of stress (CATS). Neuroscience and Biobehavioral Reviews. https://doi.org/10.1016/j.neubiorev.2009.03.001

22. Vijaydura, J., \&Vekatesh, S. (2012). A study on stress management among women college teachers in Tamilnadu, India. Pacific Business Review International, $5(2), 50-59$. 